\title{
VISUALIZATION OF FORMATIVE ASSESSMENT IN CLASSROOMS: THREE FEEDBACK QUESTIONS IN INSTRUCTIONAL PROCESSES FOR ENHANCE INDEPENDENCE TO BE A PROACTIVE LEARNER
}

\author{
Yoshihisa Nomi ${ }^{1}$ \\ ${ }^{I}$ Akita prefectural board of Education, Akita City
}

\begin{abstract}
This research is a practical study on assessment for learning that encourages independence of students in Japanese high schools implementing a biological science curriculum practices focusing in biodiversity. In order for a student to be a proactive learner, it is necessary to improve the students' self-regulation abilities. First, design classes based on the three feedback questions have practiced in the instructional process: "Where are we going?" "Where are we?" and "How will we get there?" [1]. Tablet devices were used as formative assessment tools for learning activities. This made it possible to provide students with short-term feedback from learning activities, and to observe evidence of a link with the improvement of the capacities for activeness, collaboration, and self-regulation. Furthermore, It is also effective for teachers from the aggregate results collected from the tablet devices, the learning needs of the class as a whole as well as those of individual students and groups were visualized, and it became possible to plot the integration of instruction and assessment. Finally, It has attempted to visualize the Formative assessment by teachers and students on the learning process through a unit. To achieve this, the Developing and Evaluating Measures of Formative Assessment Practices (DEMFAP) framework was adopted [2]. By visualizing formative assessment, teacher's guidance on teaching and student's learning was improved qualitatively. According to the post-research questionnaire, it seems clear that many students have improved the competency in the form of independence and cooperativeness. This paper discusses the detailed outcomes of this research.
\end{abstract}

Keywords: - Formative Assessment, proactive learner, Three Feedback Questions, DEMFAP Framework, Tablet Devices

\section{INTRODUCTION}

There are increasing demands on schools to prepare students for more rapid economic and social change, for jobs that have not yet been created, for technologies that have not yet been invented, and to solve social problems that have not been anticipated in the past [3]. As the structure of society and industry changes and there is a transition to a mature society in which qualitative affluence supports growth, we are required not only to efficiently discharge prescribed procedures, but to consider what sort of future to create and how to further improve society and life, while exercising our sensibilities, and to create new value through continuing proactive learning to draw forth our capabilities, conducting trial and error, and collaborating with other diverse people. As such there is an opportunity in forming a shared recognition between schools and society of the importance of fostering the competencies required for the new era including the knowledge to live and work through school education [4]. The educational reform in Japan coincides with international trends of the 21 st century competencies. Domestic educational policy in Japan revised the Course of Study guidelines in response to the trend of OECD. The Course of Study guidelines for 2030 treats active learning as the key concept and seeks educational reform focusing on the outcome-based assessment of "What kinds of competency can students acquire and what can they do with it?" more than content-based assessment that "What do teachers teach, and what do students learn and know?"

The PISA 2015 survey focused on science, with reading, mathematics and collaborative problem solving as minor areas of assessment and computer-based tests were used. Students also answered a background questionnaire. The questionnaire sought information about the students themselves, their homes, and their school and learning experiences [5]. Results of PISA 2015 mentioned in all the domains of scientific literacy, reading literacy and mathematical literacy, Japan continues to place in top performing group with a high mean score from an international viewpoint. On the other hand, compared with the PISA 2012 result, the mean score of reading literacy has decreased significantly. It could be deemed that shift to Computer-Based Test has certain effect on it [10]. As a reason for that, it is pointed out that Japanese high school students were not so familiar with using computer (Table-1).

Since 2020, it will start a full digital education in Japan. Programming is compulsory at elementary school. "Digital textbook" that converts paper textbook contents into electronic data becomes available. In addition, PISA 2018 
will handle "global competence" additionally. They will assesse ability to utilize the acquired knowledge, to flexibly respond in open minds in different environments, and to build relationships, skills of 'current and future needed skills' such as incorporating chat with virtual opponents on the computer. It is necessary to enrich practical lessons using ICT. We also have to establish improvement of educational guidance through evaluation of learning based on surveys and various data on the state of student.

Table-1: In student questionnaire for PISA 2015

\begin{tabular}{|l|l|}
\hline Question & Answer \\
\hline $\begin{array}{l}\text { 'Available for you to use at } \\
\text { home: Desktop computer' }\end{array}$ & $\begin{array}{l}\text { Japan is in 46th in } \\
47 \text { countries. }\end{array}$ \\
\hline $\begin{array}{l}\text { 'Available for you to use at } \\
\text { home Tablet computer' }\end{array}$ & $\begin{array}{l}\text { Japan is in 41th in } \\
47 \text { countries. }\end{array}$ \\
\hline $\begin{array}{l}\text { 'Available for you to use at } \\
\text { home Internet connection' }\end{array}$ & $\begin{array}{l}\text { Most countries are } \\
\text { over 90\%, Japan is a } \\
\text { lower level of 70\%. }\end{array}$ \\
\hline $\begin{array}{l}\text { 'Digital devices available at } \\
\text { school: Internet connection.' }\end{array}$ & $\begin{array}{l}\text { Japan is 39th in 47 } \\
\text { countries. }\end{array}$ \\
\hline $\begin{array}{l}\text { 'Digital devices available at } \\
\text { school: tablet computer'. }\end{array}$ & $\begin{array}{l}\text { Japan is 45th in 47 } \\
\text { countries. }\end{array}$ \\
\hline $\begin{array}{l}\text { 'Digital devices available at } \\
\text { school: Internet connected } \\
\text { school computers.' }\end{array}$ & $\begin{array}{l}\text { Japan is 39th in 47 } \\
\text { countries. }\end{array}$ \\
\hline
\end{tabular}

\section{AIM OF THIS REASERCH}

Improving the evaluation in the learning process can improve the quality of learning in classrooms. From the results of the PISA 2015 questionnaire survey, it is also necessary to further enhance the lesson using ICT in Japan. First, it attempts to design classes based on the three Feedback questions have practiced in the instructional process: "Where are we going?" "Where are we?" and "How will we get there?" It makes to it possible to learning activity become more continuously feedback learning outcomes. Students have tackled performance tasks with peer collaboratively by ICT on-line. Second, This study is examined with the post interview and the questionnaire how the students adjust the learning activities with formative assessment on the tasks that set by the teacher. By visualizing the student 's response to the task and the feedback for the learning in time series through the unit. It is possible to explore the clues leading to enhancement of subjective, interactive and deep learning.

\section{LITERATURE REVIEW}

Many researches on various learning outcomes at high schools and evaluation for qualitative and capacity development have been reported in Japan [6]. However, the case researches on the visualization of formative assessment of learning process are rare. Therefore, It has review overseas research on formative assessment for this study.

\subsection{Formative Assessment}

It was defined formative assessment as encompassing all those activities undertaken by teachers, and/or by their students, which provide information to be used as feedback to modify the teaching and learning activities in which they are engaged [8]. It was defined formative assessment as the process used by teachers and students to recognize and respond to student learning in order to enhance learning during the learning [7]. It was reported that formative assessment not only raises the level of student attainment, it also increases equity of student outcomes and improves attendance and students' ability to learn [9]. [10] add that many of the studies also show that improved formative assessment (or feedback) helps lower achieving students more than the rest, and so raises the overall standard of attainment while reducing the gap between higher and lower-achieving students. Australian Institute for Teaching and School Leadership reported Effective feedback practices provide the bridge between assessment and learning [11]. High quality feedback can improve student learning by as much as eight months. It is a cost-effective approach to enhancing student outcomes and it can be implemented in any education context. [12], [13] discussed the importance of "formative assessment" with feedback as the central concept, to make use of the evidence obtained from the learning process to improve learner 's learning.

Formative assessment becomes more and more important in education. However, The practical research focus on formative assessment has not so advanced in Japan. In order to enhance proactive learning, there is a necessity to shift the viewpoint of evaluation from the teacher side to the learner side, that is, we are in the paradigm shift of evaluation viewpoint.

\subsection{Three Instructional Processes}

It was mentioned three instructional processes, which have been the basis for the assessment cycle [14]. It was defined those three conditions, "Student need to understand what constitutes the goal or quality level being pursued or aimed for", " Student compare the actual level of performance with criteria", "Student engage in actions that will lead to some closure of the gap between where they are and where they should be" [12]. Formative assessment should help students move from using cause feedback to self-monitoring. It was redefined these three instructional processes as questions: "Where is the learner going?" "Where is the learner right now?" and "How does the learner get there?"[15] [16], [17] and [3] have mentioned same questions in different ways. In this study it was adopted three feedback questions from [3]. That is "Where are we going?" "Where are we now?" and "How will we get there?" These three feedback questions are key concept of instructional process in this study. Fig-1 shows "the assessment cycle activity" which is modified by author based on the Graphic Representation of the Formative Assessment Framework of [3]. 


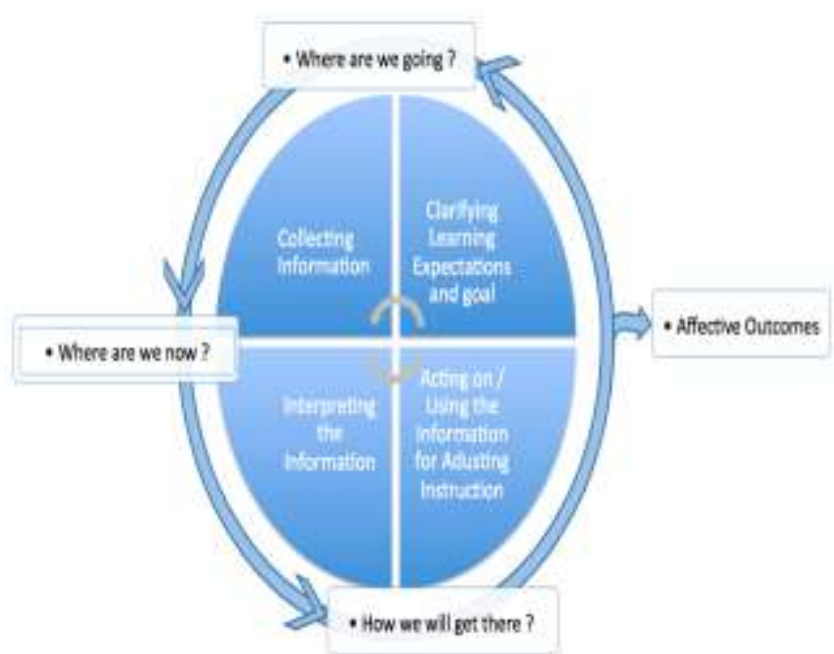

Fig-1: The Assessment Cycle

\section{METHODOLOGY}

The performance task for 67 students is to research on "crisis of biodiversity in the world", collaborate with other students, in Japanese high schools implementing a biological science curriculum practices focusing in biodiversity. Students investigate the crisis situations and causes of various species in various parts of the world including Japan by using Internet web site, books and magazines, and discuss their remedial measures. There is a list of works produced by the students (Table-2). It has considered to how students adjusted and improved their learning activities from the questionnaire surveys and interviews.

Table-2: The List of Students works (Titles of reports)

Evolutionary Paradise Galapagos Islands/Nuclear Accident and Ecosystem/Hotspot @ West Africa/ Hotspot $\sim$ New Caledonia $\sim$ /Madagascar • Whaling Issue/Endangered Species Hotspot in Southeast Asia /Endangered Species and Conservation in Africa /Endangered Species of West Japan/ Current Status and Issues of Endangered Species in Japan/Endangered Species of Hokkaido in Japan/ Ecological Crisis and Future in Japan •

Specified Alien Species/ Tuna \& Eel Impact on the Japanese Economy /Animals Inhabiting the Desert Area/Biodiversity in the Sea/European Endangered Species /Endangered species @ we will never forget Extinction of Birds in Japan /Endangered Species in South America/ Endangered Species of Antarctic penguins

\subsection{Practice of Three Feedback Questions and Formal Formative Assessment}

The formal assessment was divided into three scenes (introduction, middle, final) in this unit. Table-3 shows assessment tools and the aims based on three feedback questions at each scene.

"Where are we going?"

At the beginning of the unit, Aims of task and Rubric, clarified learning goals and evaluation criteria, have presented to students. By clearly the goal of learning for students, expectation of learning and direction of learning can be recognized. The 'guidance sheet' shows the points of learning flow and exploration activities. 'Biodiversity Rubric' (scoring index) describing the criteria for scoring the report.

\section{"Where are we?"}

It has set up scenes where students can compare their reports with others', and reconfirm the direction of learning. Encourage students to self-evaluate and ensure that the ability to coordinate learning is fostered. At the "Theme sessions", let them express their works briefly and orally. Also, the work is saved in a specific folder of the school network and converted into a digital portfolio. Create an environment where others can view works at any time. It is aimed to promote the sharing of progress of tasks among students.

"How will we get there?"

Peer assessment have implement at the final stage of the unit and set up scenes to feedback of student achievements of learning. All the reports are stored in the tablet computer, and viewing and evaluation are done at the same time. In the peer assessment using the application, the results of the counting are immediately aggregated and sent to the students and the teacher. Receive the evaluation from others and reflect it in the work, try to improve the quality of further reports. In addition, the results of counting will help teacher's support and advice to each student and class as a whole.

Table-3: Formal Formative Assessment and Purpose

\begin{tabular}{|l|}
\hline (FA) Formal Assessment (P) Purpose \\
\hline Where we going? \\
(FA) Guidance sheet (P) Clarify expectations and goals \\
for learning (FA) Biodiversity Rubric. (P) Use it as \\
a scale or ruler that will make Learning work \\
Where are we now? \\
(FA) Theme presentation. (P) Understand progress of \\
assignment(FA) Their works in Digital portfolio in \\
school on-line. (P) Sharing the progress status of tasks \\
How we there? \\
(FA) Presentation release by tablet devices \\
(FA) Peer assessment. (P) Provide immediate feedback \\
\hline
\end{tabular}




\section{DISCUSSION}

\subsection{Evidence from the Informal Formative}

\section{Assessment}

The table- 4 and -5 show evidence of the informal formative assessment such as the state of the students working on the learning, conversation, their reports and so on. It has determined the extent of interest and impression to the task from the atmosphere of the class and facial expression of the students when they have watched biodiversity movies. Advised to students made it possible to draw out the direction of learning by them.Furthermore, Information actively shared among the groups, encouraging rerecognition and mutual use of information. Not all students are fulfilling the expected learning, so we carefully observed the students and conducted informal assessment according to each student.

Table-4: Informal Formative Assessment (Enquire to Students)

\begin{tabular}{|c|c|}
\hline Eliciting & $\begin{array}{l}\text { What is the image of biodiversity? /What } \\
\text { is the environmental problems around } \\
\text { us? /Are domestic species in danger? } \\
\text { /What species are on the verge of } \\
\text { extinction in the world? /What is } \\
\text { diversity? }\end{array}$ \\
\hline Reco & $\begin{array}{l}\text { Where is the different viewpoint from } \\
\text { other groups? /Why do not you try } \\
\text { incorporating the good points of other } \\
\text { groups? /You can focus on species and } \\
\text { conservation methods in the same area. } \\
\text { /Let's investigate deeper and deeper in } \\
\text { the issue. }\end{array}$ \\
\hline Using & $\begin{array}{l}\text { Let's advance discussion within the } \\
\text { group. /Let's utilize the results of peer } \\
\text { assessment. /Why do not you look at the } \\
\text { work again from a different point of } \\
\text { view? }\end{array}$ \\
\hline
\end{tabular}

Table-5: Other Informal Formative Assessment

\begin{tabular}{|l|l|}
\hline $\begin{array}{l}\text { Movie viewing } \\
\text { in introduction } \\
\text { scene }\end{array}$ & $\begin{array}{l}\text { Measure the extent of interest } \\
\text { from the atmosphere of the } \\
\text { whole class and the expression } \\
\text { of the students. } \\
\text { Make a comment that interests } \\
\text { the movie. Promote } \\
\text { understanding and interest. }\end{array}$ \\
\hline Activity scene & $\begin{array}{l}\text { Grasp by observing how to work } \\
\text { on the activities, the activeness } \\
\text { of the conversation within the } \\
\text { group, and whether role sharing } \\
\text { is done properly. }\end{array}$ \\
\hline $\begin{array}{l}\text { The final } \\
\text { Presentation } \\
\text { scene }\end{array}$ & $\begin{array}{l}\text { Grasp the use situation of rubric } \\
\text { and from the activeness of } \\
\text { conversation during peer } \\
\text { assessment. }\end{array}$ \\
\hline
\end{tabular}

\subsection{Visualization of Formative Assessment}

Table-6 shows students' interpretation and impressions of teacher's method in each scene. It seems be inferred that the their learning are adjusted toward the learning goals. It has attempted to visualize the formative assessment by teachers and students on the learning process through a unit (Appendix.C). To achieve this, an author modified the Developing and Evaluating Measures of Formative Assessment Practices (DEMFAP) framework of [3]. By visualizing of formative assessment, it is possible to grasp the effective method and timing for the way of teaching through the whole unit, also it seems to make help student to be a proactive learner. Table-7 shows the results of the selfevaluation about the competency after the unit works.

Table-6: Student's interpretation of feedback

\begin{tabular}{|c|c|}
\hline $\begin{array}{ll}\text { Three } & \text { Feedback } \\
\text { Questions } & \end{array}$ & $\begin{array}{lll}\text { Student's interpretation } & \text { of } \\
\text { feedback }\end{array}$ \\
\hline $\begin{array}{l}\text { Where are we going? } \\
\text { Clarifying } \\
\text { LearningExpectations } \\
\text { and } \\
\text { Learning Evidence }\end{array}$ & $\begin{array}{l}\text { - I got an image on how to } \\
\text { express the task from movie } \\
\text { of biodiversity. } \\
\text { - By referring to Website of } \\
\text { WWF, NHK, Ministry of the } \\
\text { Environment Ministry, it is } \\
\text { possible to make a good } \\
\text { report. } \\
\text { - It was related to the content } \\
\text { of comprehensive learning, } \\
\text { so I was able to decide } \\
\text { immediately what to do. } \\
\text { It was an opportunity to } \\
\text { think that it would make } \\
\text { something different from } \\
\text { other groups with reference } \\
\text { to rubric. }\end{array}$ \\
\hline $\begin{array}{l}\text { Where arewe now? } \\
\text { Interpreting the } \\
\text { Information collected }\end{array}$ & $\begin{array}{l}\text { - Since I was able to listen to } \\
\text { the themes of other group, } \\
\text { We chose to proceed with a } \\
\text { different theme so as not to } \\
\text { overlap. } \\
\text { - Since there was a group that } \\
\text { chose similar themes, we } \\
\text { decided to issue originality } \\
\text { by examining in a different } \\
\text { area, specific organisms, } \\
\text { narrow range finely. } \\
\text { We asked the group working } \\
\text { next to see it and checked } \\
\text { progress of ours while } \\
\text { watching the progress of the } \\
\text { work of other group stored } \\
\text { in the PC. } \\
\text { I wrote without looking for } \\
\text { concrete examples of } \\
\text { conservation activities, but I } \\
\text { was wondering whether that } \\
\text { was good, so I asked my } \\
\text { teacher. }\end{array}$ \\
\hline
\end{tabular}




\begin{tabular}{|l|l|}
\hline $\begin{array}{l}\text { How we willget } \\
\text { there? }\end{array}$ & $\begin{array}{l}\text { We can get feedback from } \\
\text { Acting on/Using the } \\
\text { Information for } \\
\text { Adjusting Instruction }\end{array}$ \\
tablet computer. I got the \\
opportunity to lead new \\
learning which was fresh \\
and motivated and never \\
before. \\
$\begin{array}{l}\text { I can do assess by talking } \\
\text { my colleagues, also I think } \\
\text { we can know the way of } \\
\text { evaluate and think about } \\
\text { their work. I thought that I } \\
\text { could rework a good work. } \\
\text { I think the tablet is good as } \\
\text { the results are immediately } \\
\text { understood and the results } \\
\text { are saved. }\end{array}$ \\
\hline
\end{tabular}

Table-7: The post-research questionnaire of students after a unit. "What skills do you have improved?"

\begin{tabular}{|c|c|c|c|c|}
\hline & $\begin{array}{l}\text { Greatly } \\
\text { improved }\end{array}$ & $\begin{array}{l}\text { Improv } \\
\text { ed }\end{array}$ & $\begin{array}{l}\text { Slightly } \\
\text { improv } \\
\text { ed }\end{array}$ & $\begin{array}{l}\text { Not } \\
\text { improv } \\
\text { ed }\end{array}$ \\
\hline Interpersonal skills & $38.0 \%$ & $55.1 \%$ & $6.9 \%$ & $0.0 \%$ \\
\hline $\begin{array}{l}\text { Self-adjustment } \\
\text { skills }\end{array}$ & $35.7 \%$ & $50.7 \%$ & $13.6 \%$ & $0.0 \%$ \\
\hline $\begin{array}{l}\text { Problem solving } \\
\text { skills }\end{array}$ & $48.4 \%$ & $31.8 \%$ & $19.8 \%$ & $0.0 \%$ \\
\hline Predictive skills & $39.2 \%$ & $47.5 \%$ & $13.3 \%$ & $0.0 \%$ \\
\hline
\end{tabular}

(self-evaluation: 67 students )

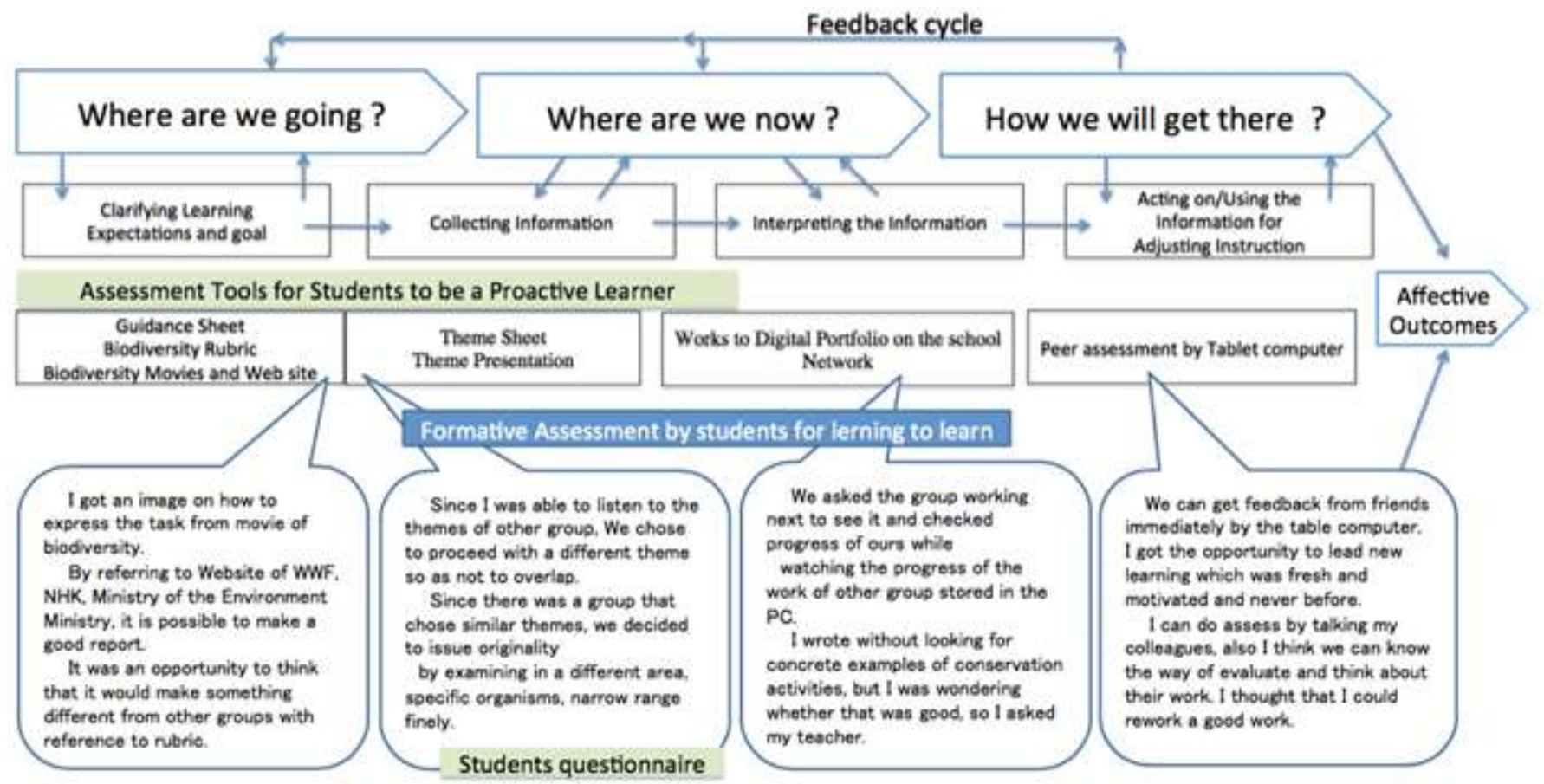

Fig-2: Visualization of formative assessment in classrooms NOTE: An author modified the DEMFAP framework of [3].

\section{CONCLUSION}

Competency in the form of independence and cooperativeness, which this practical research aimed to foster, is an academic skill that is difficult to measure. It is believed that students acquire this skill by accumulating learning opportunities. What is important is that students themselves practice formative assessment. Therefore, It is made the students aware of the goals of their learning by presenting them beforehand with guidance sheets for learning, performance tasks, and rubrics that clarified the evaluation criteria. From the post-research questionnaire and the way in which students applied themselves to their learning afterward, we deduced that many students were able to successfully proceed with their learning independently. However, every student is different when it comes to knowledge, skills, and degree of comprehension regarding learning. For that reason, it cannot be said that all students completed the deliverables associated with the prerequisites of the assignments. To bridge the gap between the prerequisites set out by the teacher and the actual performance of the students, it was necessary for the teacher to provide appropriate support and for students to become able to take a bird's-eye view of their studies. One effective strategy for accomplishing these goals is a combination of formal assessment and informal assessment. The teacher focuses their attention on the behavior and the words of the student and provides support by, for example, repeating the student's words, providing many explanations to support the 
student's thinking, and using a variety of related terms. From interviews conducted after the fact and from the questionnaire, we could infer that it is important to practice informal assessment that focuses on raising the awareness of individuals, although this awareness also grew by chance in some cases. By walking around the class as student's work and conversing with them, teachers can check students' learning while making informal assessments and allow students themselves identify the path that leads toward their goals. It is important to ensure that students acquire the abilities they need to advance in their studies, adjusting their learning as they focus on where they are going and how they can work to reach that point. It is also believed interactive learning that involves exchanging information with peers can create synergy with appropriate and well-timed support from the teacher, leading to deep learning. In Table 6, it is provided a summary of the results of the self-evaluation with regards to the qualities and skills that appear to have improved through this way of learning. It seems clear that many students have improved the qualities and skills that they will need to thrive in society.

This practical research made use of Ruiz-Primo's DEFMAP framework. This method makes it possible to objectively evaluate how a learner interpreted a teacher's support and how this support influenced students' learning. It is believed that it will be an effective assessment tool to evaluate lesson design that realizes subjective, interactive, and deep learning, and expect that it will be used more widely in the future.

It was asserted that giving feedback at the right time facilitates learning [8]. However, others have pointed out that the value of feedback about learning decreases the more time goes by until that feedback is given [17]. The tabletbased assessment it was attempted in this research is an effective way to deal with these various problems. Students advance in their learning through trial and error. During this process of trial and error, they organize their thinking through collaborative activities and adjust their learning. Furthermore, if students can get more advice about what they are doing right and what they need to work on, on the spot and at the right time, their learning becomes even more effective. It is found that when it comes to a learning design that incorporates performance assignments emphasizing context, tablet devices that are good for providing short-term feedback are useful assessment tools that enhance students' ability to adjust their learning. Also, for teachers, short-term feedback helps provide appropriate learning support that fits the learning needs of individual students and the class as a whole. Again, it is important to open students' eyes to the best ways to proceed with their learning. It is believed that learning that supports this kind of awareness by students has the potential to develop into a kind of deep learning that goes beyond even the goals that the teacher aims for. It is thought that the tablet assessment tool that was used in this practical research study can be one valid instrument that can lead to more independent and cooperative learning. For that reason, it is proposed that it be introduced proactively in learning environments. To enhance the effectiveness of formative assessment, it will be necessary to introduce and test this tool in a variety of curricula and courses in the future.

\section{ACKNOWLEDGMENT}

The author wishes to thank Masahiro Arimoto for advices on this research. This work was supported by one of JSPS KAKENHI Grant Number 17H00200.

\section{REFERENCES}

[1] Ruiz-Primo, M. A. \& Li, M. (2013). Examining formative feedback in the classroom context: New research perspectives. In J. H. McMillan (Ed.). Handbook on research on classroom assessment. 215-232. Los Angeles: Sage.

[2] Ruiz-Primo, M.A. (2010). Developing and evaluating measures of formative assessment practice (DEMFAP) theorical and methodological approach. Internal manuscript, Denver, CO: University of Colorado Denver, Laboratory for Educational Assessment, Research, and Innovation (LEARN).

[3] OECD. online. Retrieved from http://www.oecd.org/edu/school/education-2030.htm.

[4] MEXT. (2017) How we learn for better science education Improvement of science education in Japan-Key points of the revision of National Curriculum Standards of science. OECD/Japan seminar 2017 July 1.pdf

[5] OECD. (2016). PISA 2015 Results in Focus. Retrieved from https://www.oecd.org/pisa/pisa-2015results-in-focus.pdf.

[6] MEXT. (2015). Research on research methods for evaluating various learning outcomes at the Ministry of Education, Culture, Sports, Science and Technology High school, Retrieved from http://www.mext.go.jp/a_menu shotou/kaikaku/sesaku/1360966.htm.

[7] Black, P \& William, D. (1998). 'Assessment and Classroom Learning'. Assessment in Education. vol. 5(1). 7-74.

[8] Bell, B., \& Cowie, B. (1999). Researching formative for understanding pedagogy. 198-214. London: Falmer Press.

[9] OECD. (2005). 'Formative Assessment: Improving Learning in Secondary Classrooms'. Policy Brief November 2005.

[10] Black, P., \& William, D. (2010). Inside the black box: Raising standards through classroom assessment, Phi Delta Kappan, 92(1). 81-90.

[11] Australian Institute for Teaching and School Leadership (AITSL). (2016) Spotlight - Reframing feedback to improve teaching and learning.pdf.

[12] Sadler, R.D. (1987). Formative assessment and the design of instructional systems. Instructional Science. 18. 119-144. 
[13] Yamamoto, S., 2013, A Study of Feedback as Formative Assessment: Analysis on Royce Sadler's theories. Annual Bulletin, Graduate Scholl of Education, Tohoku University Vol.61 (23). 113-127.

[14] Ramaprasad, A. (1983). On the Definition of Feedback. Behavioral Science. Vol. 28(1). 4-13

[15] William, D., \& Leahy, S. (2007). A theoretical foundation for formative assessment. In J. H. McMillan (Ed.), Formative classroom assessment: Theory into practice. 29-42. New York, NY: Teachers College Press.

[16] Hattie, J., \& Timperley, H. (2007). The power of feedback. Review of Educational Research. 77 (1). 81-112.

[17] Black, P \& William, D. (2009). 'Developing the theory of formative assessment', Educational Assessment', Evaluation and Accountability, vol. 21(1). 5-31.

[18] Ilgen, D. R., Peterson R. B., Martin, B. A., \& Boeschen, D. A. (1981). Supervisor and subordinate reactions to performance appraisal sessions. Organizational Behavior \& Human Performance. 28 (3). 311-331.

\section{BIOGRAPHIE}

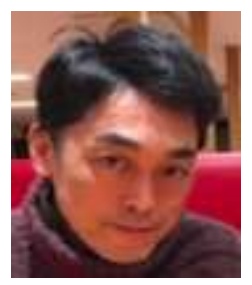

Yoshihisa nomi: Educational Supervisor. Akita prefectural board of Education, Akita City,

Japan.nomi_yoshihisa@icloud.com 